Волошина Валентина Віталіївна доктор психологічних наук, доцент, професор кафедри теоретичної та консультативної психології факультету психології, Національний педагогічний університет імені М.П.Драгоманова, вул. Пирогова, 9, м. Київ, 01601, https://orcid.org/0000-0002-4372-5824

Папітченко Лінда Вікторівна аспірантка освітньо-наукової програми «Психологія» спеціальності 053 психологія, Національний педагогічний університет імені М.П. Драгоманова, вул. Пирогова, 9, м. Київ, 01601, https://orcid.org/0000-0001-9643-7263

\title{
ПСИХОЛОГІЧНІ ОСОБЛИВОСТІ ФОРМУВАННЯ ГІДНОСТІ У МОЛОДІ 21 СТОЛІТТЯ
}

Анотація. Питання гідності особливо гостро актуалізувалось в Україні в останні вісім років. Саме жорстоке побиття мирної студентської акції протесту стала відліком початку революції Гідності, де молодь була однією з активних рушійних сил. Ці події дали нове звучання темі гідності в контексті українського поступу. Часом такі поняття, як гідність сприймаються суспільством, наче щось абстрактне, існуюче на сторінках тлумачних словників та філософських трактатів. Проте революція «Гідності» показала, що «абстрактні» гуманістичні поняття, такі, як гідність - цілком конкретні та відчутні й мають велике значення в житті людини. Тема гідності зазвучала голосніше в суспільній дискусії.

Кожна нація проходить власний шлях у процесі формування національної ідентичності. Втім найбільше утисків і намагання знівелювати державність зазнає Україна. Близько ста років українство не цінувало власну культуру, не розмовляло мовою, цуралося національних традицій. Українських письменників, науковців знищували у таборах, насаджуючи цінності пересічної люмпенізованої особистості, позбавляючи народ права на існування. Вулиці українських міст носили ім'я комуністів, які висилали до Сибіру i розстрілювали тисячі мирних жителів лише за те, що вони розмовляли українською мовою. Без сумніву, все це суттєво позначилося на ментальності декількох поколінь українців. Виживали слабкі, або ті, хто відмовлявся від свого коріння. Глибинний несвідомий страх національної пам'яті, у якій три голодомори, змушує декого і сьогодні коритися під навалою тисячолітнього 
ворога. I лише відчуття особистісної гідності кожного з нас і нації в цілому спроможне утвердити право нашого народу на власну незалежну Україну.

У психологічній царині перед нами постає ряд питань у дослідженні гідності. Для нас важливо зрозуміти й знайти відповіді на наступні питання. Як формується гідність? Які зовнішні та внутрішні чинники впливають на іiі формування? Як зміцнюється гідність особистості? Що принижує гідність особистості? Всі ці питання $€$ доволі вагомими для розуміння процесів, пов'язаних з гідністю, в психіці особистості. Й оскільки доволі часто молодь $€$ однією з основних сил рушійних процесів в суспільстві, то ми вважаємо за потрібне сконцентрувати свою увагу на формуванні гідності саме цієї вікової групи.

Ключові слова: гідність, формування гідності, детермінанти гідності, свобода, відповідальність, постколоніальне та посттоталітарне суспільство, особистість.

Voloshyna Valentyna Vitaliivna Dr. in Psychology, associate professor, professor of the department of theoretical and counseling psychology, National Pedagogical University M.P. Drahomanov, faculty of psychology, Pyrogova St., 9, Kyiv, 01601, https://orcid.org/0000-0002-4372-5824

Papitchenko Linda Viktorivna graduate student of the educational and scientific program "Psychology" specialty 053 psychology, National Pedagogical University M.P. Drahomanov,faculty of psychology, Pyrogova St., 9, Kyiv, 01601, https://orcid.org/0000-0001-9643-7263

\section{PSYCHOLOGICAL FEATURES OF THE FORMATION OF DIGNITY IN YOUTH OF THE 21ST CENTURY}

Abstract. The issue of dignity has become especially acute in Ukraine in the last eight years. It was the brutal beating of a peaceful student protest that marked the beginning of the Revolution of Dignity, where youth was one of the active drivers. The topic of dignity within the context of Ukrainian progress has assumed new importance to these events. Sometimes such concepts as dignity are perceived by society as something abstract, existing in the pages of explanatory dictionaries and philosophical treatises. However, the Revolution of Dignity has shown that «abstract» humanistic concepts, such as dignity, are very specific and tangible and are of great importance in human life. The topic of dignity became more noticeable in the public debate.

Each nation goes its own way in the process of forming a national identity. However, Ukraine suffers the most oppression and attempts to level the statehood. For about a hundred years, Ukrainians did not value their own culture, did not speak the language, and shunned national traditions. Ukrainian writers and scientists were 
exterminated in the camps, instilling the values of the average lumpenized individual, depriving the people of the right to exist. The streets of Ukrainian cities were named after communists who deported and shot thousands of civilians just because they spoke Ukrainian. Undoubtedly, all this has significantly affected the mentality of several generations of Ukrainians. The weak survived, or those who renounced their roots. The deep unconscious fear of national memory, which includes three famines, forces someone to submit even today under the pressure of a millennial enemy. And only a sense of personal dignity of each of us and the nation as a whole is able to assert the right of our people to their own independent Ukraine.

In the psychological field, we face a number of issues while studying dignity. It is important for us to understand and find answers to the following questions: How is dignity built? What external and internal factors influence its development? How is the dignity of an individual strengthened? What degrades the dignity of an individual? All these questions are quite important for understanding the processes related to dignity in the psyche of an individual. And as young people are quite often one of the main driving forces in society, we consider it necessary to focus on building the dignity of this age group.

Keywords: dignity, building of dignity, determinants of dignity, freedom, responsibility, postcolonial and post-totalitarian society, individual.

Постановка проблеми. Питання гідності $\epsilon$ важливою основою нашого щоденного життя. Тема гідності все більше лунає в суспільній дискусії, проте як невід'ємна складова повсякденного людського життя усвідомлюється незначною мірою. Досить прикро після Революції Гідності 2013 року спостерігати в Україні процеси повернення до позицій минулого сторіччя.

Аналіз останніх досліджень і публікацій. Почуття власної гідності особистості - це доволі об'ємне та багатовимірне поняття, в психологічній науці і досі існує неоднозначність щодо його розуміння і тлумачення [16]. Поняття власної гідності вченими аналізується 3 різних точок зору. Воно фігурує в працях філософів з часів Античності й до наших днів: Платона [17], Аристостеля [1], Джаноцо Манеті [18], Джовані Піко делла Мірандола [26] , П. Кравченко [7], В. Пазенюк [13], М. Дойчик [5]. Ознайомившись 3 теоретичними дослідженнями 3 філософії, педагогіки та психології ми відзначаємо одностайність поглядів науковців стосовно того, що почуття власної гідності виступає як феномен усвідомлення особистістю власної самоцінності (В. Рибалка) [19], є одним із аспектів самоставлення (I. Бех, П. Кравченко) [3; 7], виступає складовою самосвідомості особистості (В. Столін) [20], є складним інтегративним особистісним утворенням (Т. Коротковських) [9]. Натомість акцентуємо увагу на тому, що гідність як цінність, як невід'ємна складова повсякденного життя особистості вивчена недостатньо і потребує більш детального теоретико-емпіричного аналізу . 
Виклад основного матеріалу. І. Бех схарактеризував гідність особистості як усвідомлення і переживання людиною самої себе у сукупності духовноморальних характеристик, що викликають повагу оточення. Прослідковуючи історичні зміни у розумінні й ролі гідності у розвитку особистості, вчений зазначав, що поняття «гідність» як моральне ставлення особистості до світу людей і світу речей поступово трансформувалося у ставлення особистості до себе, тобто перетворилося на самоставлення. Вчений звертав увагу на специфіку психологічних механізмів відношення особистості до зовнішніх агентів і ставлення особистості до власного внутрішнього світу. За його розумінням це єдиний процес, який відбуваються із задіянням механізмів пізнавальних процесів та емоційних переживань. Для того аби дії особистості були оптимальнішими відносно себе - ій необхідно отримувати більше досвіду у взаємодії з оточуючою дійсністю, це у свою чергу детермінує домінування зовнішніх предметних дій над внутрішньо спрямованими [3].

За Л. Кулаковою почуття власної гідності - це складне інтегральне утворення, представлене єдністю суб'єктивної реальності, яка грунтується на взаємодії внутрішньособистісних і зовнішньосоціальних детермінант розвитку. Це осмислення та переживання своєї моральної цінності й суспільної значущості. Зовнішні та внутрішні чинники стимулюють прояв структурних одиниць почуття власної гідності, визначаючи спрямованість особистості. На думку вченої, критеріями прояву почуття власної гідності є: визнання власних чеснот, позитивне самоставлення та соціальноприйнятна поведінка особистості. Чинниками виступають: почуття власної гідності особистості, безумовне самоприйняття та об'єктивна самооцінка [10].

Досліджуючи образ Я особистості, Н.Чиренко дійшла висновку, що «почуття власної гідності» у структурі особистості відображається: у сформованості реалістичного образу Я, який включає в себе розуміння орієнтації у своїх чеснотах і вадах, усвідомлення своєї цінності та цінності інших; у мотивації досягнення, що включає в себе впевненість у своїх можливостях, уміння реалізувати задумане, вимірювання успіху через призму якісно-кількісних характеристик результату тощо; у особливостях вольової сфери, яка проявляється у "силі Я", тобто у здатності до успішної саморегуляції поведінки [23].

На думку філософа П.Кравченка гідність - один із найбільш складних особистісних елементів у якому одномоментно поєднується і осмислення реальної дійсності, й емоційні переживання людини, своєрідність саморегуляції поведінки, й емоційне переживання вчинків, реалізація конкретних дій, і почуття морального задоволення чи незадоволення яке виникає в результаті цього процесу [7]. У цьому сенсі Донна Хікс (Hicks Donna) зазначала, що поняття гідності актуалізує особистісні переживання. Особистість намагається переживати дії та вчинки, які на іiі думку були 
гідними або навпаки протилежними відносно неї. При цьому має бути збережена позиція свободи особистості, визнання, соціальної захищеності тощо [25] .

Розглядаючи детермінанти почуття власної гідності дослідниця Л. Кадишева виокремила детермінанти вищого та нижчого порядку. До перших відносяться зовнішні та внутрішні детермінанти. Зовнішні детермінанти зумовлюють зміст, вони з'ясовують закономірні зв'язки між величинами зовнішніх впливів і відчуттями, що їм відповідають. Будучи особистісними, детермінанти наповнюють почуття власної гідності змістом. До зовнішніх детермінант відносять суспільство, соціальні відносини, професійну сферу. Внутрішні детермінанти розглядаються як події або феномени, органічно вміщені в досліджувані явища, іманентно властиві їм. У розрізі почуття власної гідності такими чинниками $є$ індивідуально-типові властивості особистості, спрямованість особистості, а саме: ціннісні, сенсожиттєві орієнтації, локус суб'єктивного контролю. Детермінанти нижчого порядку зумовлюють способи прояву почуття власної гідності, спричинюючи його форму, тобто відображаються у позі, ході, поведінці, вчинках, словах, експресії обличчі, контролі, тощо [6].

На думку Г. Балла, проблема людської гідності тісно пов'язана зі свободою людини. Дослідник зазначав, що відсутність у більшості людей внутрішньої свободи найгостріше дається взнаки у країнах, що тривалий час зазнавали утиску тоталітарних владних режимів. В своїй науковій роботі він пише про те, що тоталітарний лад створив гострий дефіцит свободи, а його падіння - ілюзію можливості здобути іï шляхом простого зняття зовнішніх обмежень [2;24]. Значною проблемою в питанні свободи для українського народу $є$ те, за розумінням Г. Балла, що далеко не весь обсяг раптово здобутої зовнішньої свободи «людина спроможна особистісно освоїти» [2; 8] адже їі думки, переконання, страхи вже призвичаїлися до «привабливої і переконливої простоти тоталітарного впливу» [2;12] сформувавши у такий спосіб пі мислення, світогляд і уявлення про саму себе.

Наразі опанування внутрішньою та зовнішньою свободою відбувається у непростий, часом болісний, а подекуди і деструктивний спосіб, i ще складніше відбувається процес 3 оволодіння другою стороною свободи відповідальністю. В. Франкл зазначав, що свобода - це лише частина справи й половина правди. Адже бути вільним - це означає бути відповідальним. Вчений наголошував, що свобода яка проживається без відповідальності перероджується у просте свавілля [21]. Оволодіти свободою внутрішньою та зовнішньою й відповідальністю водночас - це важливий та складний психологічний урок для українського суспільства 3 огляду на його історичне минуле. Адже «в найглибшому сенсі насилля обмежує свободу» [27], а призвичаєння до «привабливої переконливості простоти тоталітарного 
мислення» [2;12] атрофує здатність особистості до пошуку складних рішень та спроможність бути відповідальним що найменше у процесі власної життєдіяльності.

Провівши попередній теоретичний аналіз соціокультурних детермінант гідності особистості загалом та в українському контексті зокрема ми дійшли висновку про наступне. Зовнішні детермінанти - це постколоніальне та посттоталітарне українське суспільство, яке поволі рухається до реалізації демократичної та гуманістичної парадигми, долаючи всі складнощі, які характерні на цьому етапі - повернення власної історії, культурної традиції, мови, тощо. Відповідно таке становище суспільства здійснює свій значний вплив на соціальні відносини [15].

Внутрішні детермінанти перебувають у стані трансформацій, адже смисложиттєві орієнтації, духовність, цінності, зокрема свобода та відповідальність, які тривалий проміжок часу насаджувались кожному українцю у вигляді комуністичної пропаганди, незважаючи на здобуття незалежності в 1991 році, й досі подекуди мають міцне укорінення в свідомості українців. Один із значних викликів для українців - це усвідомлення та оволодівання свободою й відповідальністю, як двох нерозривно пов'язаних ціннісних понять, в новій реальності - без тоталітарного або колоніального режиму, а в умовах розвитку та становлення гуманістичних і демократичних процесів у власній незалежній державі. Важливо зазначити, що саме активне громадянське суспільства демонструє значні успіхи в оволодінні свободою та відповідальністю одночасно [15].

Детермінанти нижчого порядку: поведінкові, мовленнєві та емоційні сфери особистості також перебувають на стадії змін. Після обов'язкової комуністичної сірості, яка мала своє відображення й в ході, й в словах та поведінці, наразі українці поступово опановують внутрішню та зовнішню свободу, яку ще не встигли достатньо освоїти та реалізовувати [15].

Соціокультурні чинники стали визначними у відхиленні в траєкторії розвитку гідності особистості українця. До соціокультурних детермінант ми зараховуємо: 1) соціальні, такі як загальнодержавна політика, соціальна політика, зовнішня політика, тощо, ідеологія, соціальне оточення та міжособистісні взаємодії; 2) культурні: мова, ментальність, духовно-емоційні переживання в їх широку контексті, культура вільного мислення та творчої реалізації, культура конструктивної взаємодії, культура коректного спілкування, культура в її мистецькому аспекті та ін. [15].

Висновки. Здійснивши теоретичний аналіз проблеми формування гідності особистості, нам вдалося відстежити подібність філософських і психологічних позицій у поясненні сутності цього феномену. На наш погляд, одним із провідних аспектів, на які вважаємо потрібно звернути увагу є те, що гідність розглядають, як: ставлення особистості до себе; складне інтегральне утворення, представлене єдністю суб'єктивної реальності, засноване на 
взаємодії внутрішньособистісних і зовнішньосоціальних детермінант розвитку; саморегулятор поведінки людини, i емоційне переживання своїх учинків, дій, $\mathrm{i}$ почуття морального задоволення чи незадоволення; усвідомлення своєї цінності та цінності інших. Також значимим є те, що поняття гідності межує 3 бажанням бути вільним, визнаним, зрозумілим, почутим, соціально захищеним.

Наявність єдності у механізмах ставлення особистості до власного внутрішнього світу та зовнішнього утверджує детермінованість внутрішньо особистісного переживання гідності зовнішніми впливами. Адже, стаючи особистістю через призму поглядів значущих інших, оптимальність самоставлення ми спроможні визначити лише у взаємодії з оточуючими. I це надзвичайно важливо для сучасної молоді в аспекті формування та розвитку гідності особистості в цьому віці.

Переконані, що проблема особистісної гідності сучасних українців пов’язана із відчуттям свободи і власної відповідальності, а саме не повною мірою осмислення значущості свободи із-за не бажання брати повноцінну відповідальність за власні дії та вчинки і ставати активними у життєтворенні. Враховуючи історично зумовлений український соціокультурний простір та його вплив на світосприйняття декількох поколінь поспіль, ми вважаємо, що одним iз значних викликів для українців загалом й молоді зокрема $\epsilon$ усвідомлення та оволодівання свободою й відповідальністю як двома нерозривно пов'язаними аксіологічними складовими особистісної гідності. Розуміння особистісної гідності, як умови осмислення особистісної ціннісності, має стати для прийдешніх поколінь основою формування соціокультурного виміру нової реальності побудованої на засадах європейських цінностей, гуманізму, незалежності і демократії.

\section{Jimepamypa}

1. Аристотель. (1983). Сочинения : в 4-х т. Москва: Мысль, Т. 4.

2. Балл Г.О. (2008). Орієнтири сучасного гуманізму (в суспільній, освітній, психологічній сферах): Видання друге, доповнене. - Житомир: ПП «Рута», Видавництво «Волинь».

3. Бех І. Д. (2008). Почуття гідності у духовному розвитку особистості. Теоретикометодичні проблеми виховання дітей та учнівської молоді. Київ, URL: https://core.ac.uk/download/pdf/20055001.pdf

4. Булах І.С. (2003) Розвиток моральної самосвідомості особистості підлітка: [навчальнометодичний посібник] / І.С. Булах, Ю.А. Алексєєва. К.: НПУ ім. М. П. Драгоманова

5. Дойчик М. В. (2019). Ідея гідності: від Античності до Модерну : дис. ... докт. філософ. наук : 09.00.05. Дніпро. 530 с.

6. Кадишева Л.Б. (2011). Психологічні детермінанти почуття власної гідності: дис. ... канд. психол. наук : 19.00.01. Одеса.

7. Кравченко П. А. (2002). Гідність людини як ціннісний принцип іï соціального буття. Полтава,URL: http://dspace.pnpu.edu.ua /bitstream/123456789/1984 /1/ KRAVCH.pdf

8. Ксенофонтов В. И. (1991). Духовность как экзистенциальная проблема // Филос. науки. - № 12.

9. Коротковских Т.В. (2004). Формирование основы чувства собственного достоинства у старшего дошкольника в самопроцессах: дис. ...канд. психол. наук: 19.00.07. Казань. 
10. Кулакова Л.М. (2014). Почуття власної гідності як конструкт самосвідомості особистості. Збірник наукових праць К-ПНУ імені Івана Огієнка, Інституту психології імені Г.С.Костюка НАПН України.

11. Куницына В. Н. (1998). Сила Я и самоуважение / Психология: Учебник / Под ред. А. А. Крылова. Москва : Проспект

12. Мамардашвілі М.К. (1991). Думка приневолювана: Розмова 3 Анні Епельбоїн // Філос. і соціол. думка. № 11 .

13. Пазенок В. (2005). Гуманістичний принцип сучасної філософії освіти. Філософія освіти. С. 52-64.

14. Папітченко Л.В. (2020). Гідність як смисложиттєва цінність сучасної особистості. Науковий журнал «Проблеми сучасної психології» № 17. Запоріжжя,. URL: http://www.journalsofznu.zp.ua/index.php/psych/article/view/1511/1448?fbclid=IwAR3mg9n1LH EaRukiD9y8oGDjLFLtnOcegzRyV1YZUSJBSOvnNioa80hXOI4

15. Папітченко Л.В. (2020). Соціокультурні детермінанти розвитку гідності особистості через призму постколоніального та посттоталітарного українського наративу. фахове видання Інституту психології імені Г. С. Костюка "Психологічний часопис" Том 6 № 12 URL:https://www.apsijournal.com/index.php/psyjournal/article/view/1133/ 710?fbclid= IwAR3fyXqubBGtUtJ4M76MopEAu7ZecwgoQ3mCf0Stdsx3decM2qc6Efv5A

16. Папітченко Л.В. (2020). Філософсько-психологічні аспекти зародження феномену гідності особистості від античності до епохи відродження. - фахове видання "HABITUS” № 15.

17. Платон. (1971). Государство. Собрание сочинений: в 3 т., Т.3. Москва: Мысль. C. $327-629$.

18. Ревякина Н.В. (1975). Итальянское Возрождение. Гуманизм второй половины XIV - первой половины XV в. Новосибирск: НГУ.

19. Рибалка В. В. (2010). Психологія честі та гідності особистості: культурологічні та аксіологічні аспекти: наук.-метод. посіб.; НАПН України, Ін-т пед.освіти і освіти дорослих; Ін-т обдарованої дитини, МОН України, Укр. наук.-метод. центр практ. психології і соц. роботи. Київ-Вінниця: ТОВ Фірма «Планер».

20. Столин В.В. (1983). Самосознание личности. М.: МГУ.

21. Франкл В. (1990). Человек в поисках смысла. М.: Прогресс.

22. Чеснокова И. И. (1977). Проблема самосознания в психологии. М.: Наука.

23. Чиренко Н.В. (2008). Почуття власної гідності: критерії та показники. Інститут проблем виховання АПН України 1 (12), 115-119 URL: http://lib.iitta.gov.ua/4817/1/ \%D0\%A7\%D0\%B8\%D1\%80\%D0\%B5\%D0\%BD\%D0\%BA\%D0\%BE_2008.pdf

24. Шрейдер Ю. (1994). Ценности, которые мы выбираем // Новый мир. № 8.

25.Hicks Donna (2013). Ph.D. What Is the Real Meaning of Dignity? URL: https://www.psychologytoday.com/us/blog/dignity/201304/what-is-the-real-meaning-dignity-0

26. Lebech M. (2004). What is Human Dignity? Maynooth Philosophical Papers / ed. by M. Lebech. Maynooth.

27. Robustelli F. (2005). Rationality as an alternative to violence. Milan: Prometeo.

\section{References:}

1. Aristotel' (1983). Sochinenija [Essays]. (Vols. 1-4). Moskva: Mysl' [in Russian].

2. Ball, G.O. (2008). Oricntiri suchasnogo gumanizmu (v suspil'nij, osvitnij, psihologichnij sferah) [Landmarks of modern humanism (in social, educational, psychological spheres)]. (Vols. 1-2). Zhitomir: PP «Ruta», Vidavnictvo «Volin'» [in Ukrainian].

3. Beh, I. D. (2008). Pochuttja gidnosti u duhovnomu rozvitku osobistosti. Teoretiko-metodichni problemi vihovannja ditej ta uchnivs'koï molodi [Sense of dignity in the spiritual development of the 
individual. Theoretical and methodological problems of raising children and students]. Kiïv. core.ac.uk. Retrived from https://core.ac.uk/download/pdf/20055001.pdf in Ukrainian].

4. Bulah, I.S. (2003) Rozvitok moral'noï samosvidomosti osobistosti pidlitka [Development of moral self-consciousness of a teenager's personality]. K.: NPU im. M. P. Dragomanova [in Ukrainian].

5. Dojchik, M. V. (2019). Ideja gidnosti: vid Antichnosti do Modernu [The idea of dignity: from antiquity to modernism]. Doctor's thesis. Dnipro [in Ukrainian].

6. Kadisheva, L.B. (2011). Psihologichni determinanti pochuttja vlasnoï gidnosti [Psychological determinants of self-esteem]. Candidate's thesis. Odesa. [in Ukrainian].

7. Kravchenko, P. A. (2002). Gidnist' ljudini jak cinnisnij princip iii social'nogo buttja [Human dignity as a value principle of its social existence]. Poltava. dspace.pnpu.edu.ua. Retrived from http://dspace.pnpu.edu.ua /bitstream/123456789/1984 /1/ KRAVCH.pdf [in Ukrainian].

8. Ksenofontov, V. I. (1991). Duhovnost' kakjekzistencial'naja problema [Spirituality as an existential problem]. Filos. nauki - Philos. science, 12 [in Russian].

9. Korotkovskih, T.V. (2004). Formirovanie osnovy chuvstvasobstvennogo dostoinstva u starshego doshkol'nika $\mathrm{v}$ samoprocessah [Formation of the basis of self-esteem in senior preschoolers in self-processes].Candidate's thesis. Kazan [in Russian].

10. Kulakova, L.M. (2014). Pochuttja vlasnoï gidnosti jak konstrukt samosvidomosti osobistosti [Self-esteem as a construct of personal self-awareness]. Zbirnik naukovih prac' K-PNU imeni Ivana Ogienka, Institutu psihologiï imeni G.S.Kostjuka NAPN Ukraïni - Collection of scientific works of K-PNU named after Ivan Ogienko, Institute of Psychology named after GS Kostyuk NAPS of Ukraine [in Ukrainian].

11. Kunicyna, V. N. (1998). Sila Ja i samouvazhenie [Strength I and self-esteem]. Moskva: Prospekt [in Russian].

12. Mamardashvili, M.K. (1991). Dumka prinevoljuvana: Rozmova z Anni Epel'boïn [Thought is enslaved: Conversation with Annie Epelboin]. Filos. i sociol. dumka - Philos. and sociol. opinion, 11 [in Ukrainian].

13. Pazenok, V. (2005). Gumanistichnij princip suchasnoï filosofiï osviti [The humanistic principle of modern philosophy of education]. Filosofija osviti - Philosophy of education, 52-64 [in Ukrainian].

14. Papitchenko, L.V. (2020). Gidnist' jak smislozhittevacinnist' suchasnoï osobistosti [Dignity as the meaning of life of the modern personality]. Naukovij zhurnal «Problemi suchasnoï psihologiï» - Scientific journal "Problems of modern psychology", 17. www.journalsofznu.zp.ua. Retrived from http://www.journalsofznu.zp.ua/index.php/psych/article/view/1511/ 1448?fbclid= IwAR3mg9n1LHEaRukiD9y8oGDjLFLtnOcegzRyV1YZUSJBSOvnNioa80hXOI4 [in Ukrainian].

15. Papitchenko, L.V. (2020). Sociokul'turni determinanti rozvitku gidnosti osobistosti cherez prizmu postkolonial'nogo ta posttotalitarnogo ukraïns'kogo narativu [Sociocultural determinants of personal dignity development through the prism of postcolonial and posttotalitarian Ukrainian narrative].Psihologichnij chasopis - Psychological Journal, 6, 12. www.apsijournal.com Retrived from https://www.apsijournal.com/index.php/psyjournal/article/view/1133/ 710?fbclid= IwAR3fyXqubBGtUtJ4M76MopEAu7ZecwgoQ3mCf0Stdsx3decM2qc6Efv5A [in Ukrainian].

16. Papitchenko, L.V. (2020). Filosofs'ko-psihologichni aspekti zarodzhennja fenomenu gidnosti osobistosti vid antichnosti do epohi vidrodzhennja [Philosophical and psychological aspects of the origin of the phenomenon of personal dignity from antiquity to the Renaissance]. HABITUS - HABITUS, 15. [in Ukrainian].

17. Platon, (1971). Gosudarstvo [The state]. (Vols. 1-3). Moskva: Mysl' [in Russian].

18. Revjakina, N.V. (1975). Ital'janskoe Vozrozhdenie. Gumanizm vtoroj poloviny XIV pervoj poloviny XV v. [Italian Renaissance. Humanism of the second half of the XIV - first half of the XV century]. Novosibirsk: NGU [in Russian]. 
19. Ribalka, V. V. (2010). Psihologija chesti ta gidnosti osobistosti: kul'turologichni ta aksiologichni aspekti [Psychology of honor and dignity of the individual: culturological and axiological aspects]. Kiïv-Vinnicja: TOV Firma «Planer» [in Ukrainian].

20. Stolin, V.V. (1983). Samosoznanie lichnosti [Self-awareness of the person]. M.: MGU [in Russian].

21. Frankl, V. (1990). Chelovek v poiskah smysla [Man in search of meaning]. M.: Progress [in Russian].

22. Chesnokova, I. I. (1977). Problema samosoznanija v psihologii [The problem of selfawareness in psychology]. M.: Nauka [in Russian].

23. Chirenko, N.V. (2008). Pochuttja vlasnoï gidnosti: kriteriï ta pokazniki [Self-esteem: criteria and indicators]. Institut problem vihovannja APN Ukraïni - Institute of Problems of Education of the Academy of Pedagogical Sciences of Ukraine, 1 (12), 115-119. lib.iitta.gov.ua . Retrived from http://lib.iitta.gov.ua/4817/1/\%D0\%A7\%D0\%B8\%D1\%80\%D0\%B5\%D0\%BD\% D0\%BA\%D0\%BE_2008.pdf [in Ukrainian].

24. Shrejder, Ju. (1994). Cennosti, kotorye my vybiraem [The values we choose]. Novyj mir New World, 8 [in Russian].

25.Hicks Donna (2013). Ph.D. What Is the Real Meaning ofDignity? URL: https://www.psyc hologytoday.com/us/blog/dignity/201304/what-is-the-real-meaning-dignity-0

26. Lebech M. (2004). What is Human Dignity? MaynoothPhilosophical Papers / ed. by M. Lebech. Maynooth.

27. Robustelli F. (2005). Rationality as an alternative toviolence. Milan: Prometeo. 